\title{
Gaya Penerjemahan "Funktionsvergfüge" Pada Novel Herr Der Diebe Karya Cornelia Funke
}

\author{
Uryadi \\ Fakultas Bahasa dan Seni, Universitas Negeri Jakarta \\ Email: uryadirohimin@unj.ac.id
}

E-ISSN : 2579-4574

P-ISSN : 2549-7359

\begin{abstract}
The objective of this research is to analyze the translation of German "Funktionsverbgefüge" (verbal-nominal constructions) into bahasa and to find out the understanding of translating procedure, the equivalences and deviations in translating the forms. This research methodology is qualitative using content analysis technique. Data were sentences using the FVG. They were taken from a roman "Herr der Diebe" by Cornelia Funke and its version in bahasa. There were 137 FVG found and analyzed. The result of this research shows that (1) there are expressions using FVG were translated with five translating procedure, (2) it was found that the translated phrases habe communicative equivalences with the source sentences, and (3) the translating deviations found were most becouse of the translators failure in finding the right words.
\end{abstract}

Keywords: Translation, FVG. Funktionsverbgefüge, Verbal-Nominal Constructions

\section{https://ojs.unm.ac.id/eralingua}

\section{PENDAHULUAN}

Seiring dengan perkembangan ilmu pengetahuan dan teknologi, kemampuan berbahasa manusia pun semakin berkembang (Saleh, Saud, \& Asnur, 2018; Soloway, Norris, \& Hossain, 2011). Hubungan antar negera dan kemampuan berkomunikasi dalam bahasa asing menjadi sebuah keniscayaan. Kemampuan berbahasa asing tidak hanya membantu untuk berkomunikasi tetapi juga untuk menyerap pengetahuan yang ditulis dalam bahasa asing tersebut. Karena itu, penguasaan satu bahasa saja belum cukup, tetapi diperlukan juga penguasaan bahasa asing (Wael, Asnur, \& Ibrahim, 2018). Dengan menguasai lebih dari satu bahasa, kesempatan untuk memperluas wawasan dan pengetahuan juga semakin besar. Namun karena tidak semua orang menguasai bahasa asing, maka informasi tentang ilmu pengetahuan dan teknologi dari negara lain yang ditulis dalam bahasa asing tersebut hendaknya diterjemahkan. Dengan demikian, perkembangan ilmu pengetahuan dan teknologi tidak akan terhambat berkat adanya buku-buku terjemahan yang dihasilkan dari kegiatan penerjemahan. Orang yang tidak menguasai bahasa asing tetap dapat mengembangkan wawasannya dengan membaca 
buku- buku hasil terjemahan tersebut.

Kegiatan penerjemahan yang berperan penting sebagai jembatan penghubung antara dua bahasa yang berbeda ini tidak hanya terjadi pada bidang ilmu pengetahuan dan teknologi, tetapi juga pada bidang sastra. Untuk dapat memerankan peran sentral ini, maka penerjemah harus menguasai bahasa sumber (BSu) dan juga bahasa sasaran (BSa). Penguasan dalam bidang tatabahasa adalah salah satunya (Joyce, 2018; Oppenheim dkk., 2018; Dennis, 2019; Shadiev dkk., 2018; Ying dkk., 2018). Bahasa Jerman yang merupakan kelompok bahasa indogerma memiliki karakter yang berbeda dengan bahasa Indonesia. Salah satu bentuk kalimat yang harus dikuasai oleh penerjamah dengan BSu Jerman adalah Funktionsverbgefüge (FVG). Hal ini disebabkan karena bentuk kalimat yang mengunakan FVG mempunyai kekhasan yang tidak ditemukan dalam BSa dalam hal ini bahasa Indonesia. FVG mempunyai bentuk yang beraneka yang bentuk-bentuk tersebut memiliki makna yang berbeda pula. Penerjemah tidak bisa mengartikan kalimat dengan FVG secara harfiah karena teks sasaran (Tsa) tidak hanya akan terdengar kaku tetapi dapat bermakna berbeda dari TSa sehingga ketidaksepadanan makna yang kemudian akan terjadi penyimpangan makna.

Bentuk kalimat dengan FVG dapat ditemukan di semua jenis teks, tidak terkecuali dalam novel Herr der Diebe karya Cornelia Funke. Penulis memilih novel ini menjadi korpus data karena dilandasi beberapa pertimbangan. Yang pertama adalah karena penulis novel ini adalah salah satu penulis yang karyanya selalu ditunggu pembaca, tidak hanya di Jerman tetapi juga di dunia karena karyanya banyak dialihbahasakan ke dalam berbagai bahasa di dunia. Banyak karyanya menjadi best seller dan mendapat penghargaan dan difilmkan. Salah satu dari karya tersebut adalah novel Herr der Diebe. Novel ini tidak hanya menjadi best seller, diterjemahkan ke banyak bahasa, difilmkan dan juga mendapat penghargaan sebagai novel remaja. Alasan kedua pemilihan novel ini sebagai korpus data adalah karena fenomena yang melekat pada novel ini. Alasan ketiga adalah karena novel ini banyak mengandung kalimat dengaan FVG sehingga korpus data dapat mewakili untuk dianalisa dan dibuat kesimpulan. Pertimbangan terakhir dari pemilihan novel ini adalah karena faktor penerjemah. Hendarto Setiadi adalah praktisi penerjemah bahasa Jerman yang dikenal baik di Indonesia. Banyak buku bahasa Jerman yang sudah ia terjemahkan ke dalam bahasa Indonesia. Selain menjadi penerjemah, ia juga adalah seorang interpreter. Pusat kebudayaan Jerman dan kedutaan asing berbahasa Jerman sering menggunakan jasanya untuk berbagai acara seperti seminar dan konferensi.

\section{KAJIAN LITERATUR}

\section{Definisi Penerjemahan}

Penerjemahan adalah kegiatan mengalihkan pesan secara tertulis dari satu bahasa ke 
dalam bahasa yang lain. Karena penerjemahan berfungsi mengalihkan pesan, maka dapat dikatakan bahwa penerjemahan merupakan sebuah proses komunikasi, dalam hal ini penerjemah adalah penerima pesan dari teks sumber dan pesan yang sama harus diterima oleh pembaca hasil terjemahan (Namikawa dkk., 2018; Santos dkk., 2015; Mihyung dkk., 2016). Terdapat beberapa definisi penerjemahan di antaranya seperti yang dikemukakan Snell-Hornby (1998:37) yang membedakan penerjemahan yang bersumber dari teks tulis dan penerjemahan lisan (interpreter):

Wir verstehen daher unter Übersetzen die Translation eines fixierten und demzufolge permanent dargebotenen bzw. beliebig oft wiederholbaren Textes der Ausgangssprache in einen jederzeit kontrollierbaren und wiederholt korrigierbaren Text der Zielsprache. Unter Dolmetschen verstehen wir die Translation eines einmalig (in der Regel mündlich) dargebotenen Textes der Ausgangssprache in einen nur bedingt kontrollierbaren und infolge Zeitmangels kaum korrigierbaren Text der Zielsprache.

Hornby menyebutkan bahwa dalam penerjemahan yang bersumber pada teks, seorang penerjemah masih bisa mengoreksi dan mengontrol hasil terjemahan, sementara pada pada penerjemahan lisan hal itu tidak bisa dikakukan. Kade menggunakan istilah Übersetzen untuk penerjemahan yang bersumber teks tulis dan istilah Dolmetschen untuk penerjemahan lisan dan menempatkan kedua istilah ini di bawah istilah Translation. Definisi lain dikemukakan oleh Wills (1977:72) yang mengemukakan:

Übersetzen ist ein Textverarbeitungs- und Textreverbalisierungsproze $\beta$, der von einem ausgangssprachlichen Text zu einem möglichst äquivalenten zielsprachlichen Text hinüberführt und das inhaltliche und stilistische Verständnis der Textvorlage voraussetzt.

Übersetzen ist demnach ein in sich gegliederter Vorgang, der zwei Hauptphasen umfaßt, eine Verstehensphase, in der der Übersetzer den ausgangssprachlichen Text auf seine Sinn- und Stilintention hin analysiert, und eine sprachliche Rekonstruktionsphase, in der der Übersetzer den inhaltlich und stilistisch analysierten ausgangssprachlichen Text unter optimaler Berücksichtigung kommunikativer Äquivalenzgesichtspunkte reproduziert. 
Wilss memandang penerjemahan sebagai sebuah proses yang pada akhir proses tersebut diperoleh equivalensi antara teks sumber (TA) dan teks sasaran (TS) dan kesepadanan tersebut diperoleh setelah penerjemah melakukan rangkaian kegiatan yang berurutan. Phase-phase tersebut adalah (1) phase menganalisa dan memahami teks sumber dan (2) phase rekonstruksi TSa. Pendapat yang sama dikemukakan oleh Wilss (2011), penerjemahan sebagai sebuah proses. Menurutnya, penerjemahan adalah "der Vorgang der schriftlichen Umsetzung eines Textes aus einer Sprache (AS) in andere Sprache (ZS)" (proses pemindahan sebuah teks tulis dari bahasa sumber (BSu) ke dalam bahasa sasaran (BSa). sehingga ia menyebutkan bahwa sebuah penerjemahan sebagai sebuah hasil (produksi) sebuah pemindahan teks.

Sementara menurut Retsker (2019), penerjemahan berisikan pengalihan dari teks sumber ke dalam bahasa sasaran. Menerjemahkan adalah kegiatan menghasilkan makna, pesan, informasi, atau gagasan kembali di dalam bahasa penerima secara sedekat dekatnya dan sewajar - wajarnya sepadan dengan pesan dalam bahasa sumber, pertama menyangkut maknanya, dan kedua menyangkut gayanya. Begitupula dengan Jakobson (2013) mengungkapkan bahwa penerjemahan sebagai "the replacement of textual material in one language $(S L)$ by equivalent textual material in another language $(T L)$.

Dari pengertian-pengertian penerjemahan yang telah disebutkan di atas memiliki kesamaan pengertian bahwa penerjemahan secara umum adalah pengalihan bahasa sebuah kata, kalimat atau teks dari satu bahasa ke bahasa yang lain dengan mempertahankan pesan sehingga pembaca sebuah produk penerjemahan memiliki pesan yang sama dengan pembaca teks sumber.

\section{Hakikat Prosedur Penerjemahan}

Dalam penerjemahan terdapat dua istilah yang sering digunakan yaitu metode (Übersetzungsmethode)_dan prosedur penerjemahanan (Übersetzungsverfahren). SnellHornby (1998:151) mengemukakan bahwa metode penerjemahan adalah strategi penerjemahan yang mengacu pada keseluruhan teks. Dalam penerjemahan dibicarakan antara lain masalah jenis teks yang akan dihasilkan dari proses terjemahan itu atau apa siapa pembaca penerjemahan itu. Sementara prosedur penerjemahan adalah mengacu pada kalimat yang akan diterjemahkan. Bagaimana sebuah kalimat atau potongan teks dalam Bsu diterjemahkan ke dalam Bsa. Prosedur penerjemahan dapat pula dikatakan sebagai tehnik penerjemahan (Übersetzungstechniken).

Koller (2011) membagi potensi kesepadanan dalam ranah leksikal menjadi lima jenis, yaitu:

a. kesepadanan satu menjadi satu (die Eins-zu-eins-Entsprechung, Äquivalent) muncul apabila setiap istilah dalam BSu memiliki satu padanan istilah dalam Bsa

b. kesepadanan satu menjadi banyak (die Eins-zu-viele-Entsprechung, Diversifikation) 


\section{Eralingua: Jurnal Pendidikan Bahasa Asing dan Sastra Vol.3, No.2, Agustus 2019}

apabila suatu istilah dalam BSu memiliki banyak padanan dalam BSa

c. kesepadanan banyak menjadi satu (die Viele-zu-eins-Entsprechung, Neutralisation) merupakan kebalikan dari kesepadanan satu menjadi banyak. Jenis kesepadanan ini muncul apabila beberapa istilah dalam BSu hanya memiliki satu padanan dalam BSa

d. kesepadanan satu menjadi sebagian (die Eins-zu-Teil-Entsprechung) ditemukan pada istilah dalam BSu yang hanya sebagian maknanya saja yang diwakili oleh istilah dalam BSa. Dengan kata lain bahwa makna yang terkandung dalam istilah BSa lebih luas dari pada istilah dalam BSu

e. kesepadanan satu menjadi nol (die Eins-zu-Null-Entsprechung, Lücke) muncul apabila suatu istilah dalam BSu tidak memiliki padanan dalam BSa sehingga terdapat kekosongan padanan kata. Permasalahan ketakterjemahan ini dalam bahasa Jerman dikenal dengan istilah Unübersetzbarkeit

Apa yang dikemukakan Koller dalam teori diatas adalah penerjemahkan pada tataran kata bukan kalimat, sehingga teori tersebut kurang tepat jika digunakan untuk tujuan menganalisis FVG, karena menganalisis FVG adalah berada pada tataran kalimat. Karena alasan tersebut, maka penulis menggunakan teori yang dikembangkan oleh Hornby. la membuat panduan mengenai kemungkinan-kemungkinan perubahan sebuah kalimat yang akan diterjemahkan (Snell-Hornby, 1998). Karena penulis hanya berkonsentrasi pada jenis kalimat yang mengandung unsur FVG sehingga penulis hanya akan menggunakan prosedur penerjemahan yang berkaitan dengan struktur kalimat (Grammatik);

a. Wort für Wort Übersetzung (G1)

Dalam teknik penerjemahan ini, sebuah kata diterjemahkan langsung dengan cara mempertahankan jumlah, jenis dn posisi kata-kata tersebut.

Contoh: Where he is? - Wo ist er?

b. Permutasi (G2)

Dalam teknik penerjemahan ini penerjemah mengubah posisi dari salah satu bagian kalimat yang akan diterjemahkan.

Contoh: I have read the book.-Ich habe das Buch gelesen.

c. Exspansi (G3)

Pada teknik penerjemahan ini penerjemah menambah jumlah kata sehingga kata-kata dalam kalimat dalam Bsa lebih banyak dari Bsu.

d. Reduksi (G4)

Berlawanan dengan ekspansi, pada teknik reduksi, penerjemah mengurangi jumlah kata dalam kalimat Bsa sehingga kalimat hasil terjemahan lebih singkat.

e. Intrakategorialer Wechsel (G5)

Dalam teknik ini penerjemah membuat perubahan, akan tetapi masih didalam satu 
kategori grammatik. Misalnya penerjemah mengganti kata sandang tertentu (def. Pronoun) menjadi tanpa kata sandang (Nullartikel).

f. Transposisi (G6)

Pada teknik ini penerjemah membuat perubahan jenis kata, sehingga sebuah kata sifat dalam Bsu bisa saja berubah menjadi Nomina dalam Bsa.

g. Transformasi (G7)

Pada teknik ini penerjemah mengubah susunan kalimat (konstruksi sintaksis) sehingga penerjemah tidak selalu mempertahankan jenis kalimat yang sama untuk Bsa.

\section{METODE PENELITIAN}

Penelitian ini adalah jenis kualitatif untuk menghasilkan data deskriptif berupa kata-kata tertulis atau lisan (Moleong, 2017). Adapun pendekatan penelitian ini yaitu menggunakan analisis isi yang mengkaji klasifikasi lambang-lambang dalam komunikasi melalui berbagai jenis analisis teks tertulis. Sumber data penelitian ini diperoleh dari objek penelitian yang sekaligus sebagai sumber informasi yaitu Novel Herr Der Diebe Karya Cornelia Funke. Teknik pengumpulan data penelitian dilakukan dengan mengidentifikasi data utama yang terdapat pada novel tersebut dan yang berkaitan dengan judul penelitian.

Prosedur analisis isi ini dilakukan secara bertahap dan sistematis melalui langkah-langkah sebagai berikut:

1. Seleksi Data artinya keseluruhan teks diidentifikasi secara umum dan dilakukan seleksi terhadap teks yang berkaitan dengan tema atau judul.

2. Menentukan Unit Analisis dapat dimaknai sebagai hasil identifikasi dan seleksi data yang selanjutnya dilakukan penentuan. Unit data yang ditentukan diambil dari teks atau dialog yang mengandung unsur Funktionsvergfüge dalam novel Herr Der Diebe Karya Cornelia Funke.

3. Mengembangkan Kategori artinya bahwa setelah penentuan unit analisis selanjutnya dikategorisasikan dan diklasifikiasikan sehingga dapat diperoleh data yang sesuai dan seimbang. Kategori tersebut dilakukan sesuai dengan tujuh prosedur penerjemahan berdasarkan dengan struktur kalimat (Gramatik) (SnellHornby, 1998)

4. Analisis Data dilakukan berdasarkan intensitas unit yang ada dari setiap kategori dalam sumber data yang sekaligus sebagai petunjuk terhadap temuan penelitian. 


\section{HASIL DAN PEMBAHASAN}

1. Funktionsverbgefüge (FVG)

a. Funktionsverb (FV) dan Funktionsverbgefüge (FVG)

FVG terdiri dari dua bagian yaitu Funktionsverb (FV) dan sebuah kata benda (Nomina). Dua unsur itu membentuk sebuah kesatuan semantik dan predikat. (Helbig \& Buscha, 2001). FV dalam FVG adalah adalah sebuah kata kerja bantu (Hilfverben) dan bukan kata kerja utuh (Vollverben). Oleh karenanya FV tidak bisa berdiri sendiri untuk membentuk sebuah predikat, akan tetapi membutuhkan bagian lain dari FVG yaitu sebuah Nomina. FV dan Nomina dalam FVG merupakan sebuah kesatuan.

Berikut contoh kalimat dengan konstruksi FVG.

Contoh: (1) "Hör endlich auf, dir Sorgen zu machen".

(Berhentilah membuat dirimu khawatir)

(Sudahlah, jangan khawatir terus)

Nomina Sorgen (Kekhawatiran) pada kalimat tersebut tidak dapat berdiri sendiri akan tetapi harus diikuti oleh verba machen. Verba machen (melakukan) dalam kalimat tersebut hanya bersifat membantu membentuk kalimat konstruksi FVG. Makna pada konstruksi tersebut ada pada nomina Sorgen.

Contoh: (2) Wespe warf einen wachsamen Blick nach links und rechts.

(Tawon melemparkan Pandangan yang seksama ke kiri dan ke kanan)

( Dengan waspada Tawon menengok ke kiri dan ke kanan.)

Pada kalimat ini konstruksi FVG yang digunakan adalah einen Blick werfen.

Nomina Blick dan verba werfen adalah satu kesatuan untuk membentuk konstruksi FVG. Makna kalimat tersebut ada pada nomina Blick dan verba werfen berfungsi sebagai kata bantu dan tidak mewakili makna sebenarnya dari verba itu.

\section{b. FVG dalam Bahasa Indonesia}

Berbeda dengan bahasa Jerman yang memiki konsep FVG dan dalam proses pembelajaran bahasa Jerman menjadi objek penting untuk diketahui siswa. Konsep FVG ini juga dapat kita temukan di banyak buku-buku pegangan gramatik bahasa Jerman. Namun sebaliknya, dalam bahasa Indonesia konsep FVG tidak kita temukan. Akan tetapi karakteristik FVG dapat kita temukan dalam bahasa Indonesia. Pada kalimat (1) Meskipun sibuk bekerja, si ibu selalu memberikan perhatian kepada anaknya. Verba memberikan pada kalimat di atas tidak bisa berdiri sendiri tetapi harus digunakan bersama dengan nomina perhatian. Konstruksi keduanya (memberikan perhatian) sama dengan makna verba memperhatian. Sama seperti dalam bahasa Jerman, makna konsstruksi tesebut ada pada bagian nomina perhatian, sedangkan verba memberikan hanya untuk penyempurna kalimat dan berfungsi sebagai predikat dan kehilangan makna leksikalnya. Makna 
memberikan pada contoh kalimat di atas berbeda dengan (2) Guru itu selalu memberikan PR untuk murid-muridnya. Kata memberikan pada kalimat tersebut memiliki makna sendiri.

Namun demikian bahasa Indonesaia juga mengenal istilah kata kerja bantu akan tetapi dengan istilah yang berbeda, tetapi memiliki fungsi yang sama, yaitu kata tersebut hanya memiliki fungsi gramatikal. Dalam bahasa Indonesia dikenal dengan istilah kata tugas. Alwi mengungkapkan bahwa kata tugas hanya memiliki arti gramatikal akan tetapi tidak meiliki arti leksikal. Arti suatu kata tugas ditentukan bukan oleh kata itu secara lepas melainkan oleh kaitannya dengan kata lain dalam frasa atau kalimat (Alwi, Dardjowidjojo, Lapoliwa, \& Moeliono, 2000). Fungsi ini sama dengan FV dalam kontek pembahasan FVG. Namun demikian FVG atau dalam istilah umum dikenal sebagai verb-nominal constructions dalam bahasa Indonesia tidak banyak dikenal.

Hal yang berbeda kita temukan pada bahasa Jerman. Untuk konstruksi kalimat (1), bahasa Jerman menggunakan verba schenken (menghadiahi) bukan verba geben (memberikan) seperti bahasa Indonesia. Sehingga padanan yang tepat dan berterima untuk kalimat (1) adalah Obwohl die Mutter beruflich sehr beschäftig ist, schenkt sie ihrem Sohn immer Aufmerksamkeit.

Perbedaan inilah yang harus diperhatikan oleh penerjemah. Jika ia terlalu berorientasi kepada TSu, maka kemungkinan besar ia akan membuat kessalahan dalam menggunakan verba yang tepat.

\section{Kesepadanan Makna Dalam Penerjemahan}

Sama halnya dengan definisi tentang penerjemahan, terhadap beragam pendapat mengenai maksud kesepadanan atau equivalance dalam konteks penerjemahan. Kesepadanan dapat diklasifikasikan dalam dua kategori, yakni kesepadanan formal dan kesepadanan dinamis. Kesepadanan formal berorientasi pada teks sumber. Penerjemahan didesain untuk menghadirkan teks bahasa sasaran yang sama dengan bentuk dan isi esan pada teks bahasa sumber. Dalam menghasilkan kesepadanan formal yang harus diperhatikan, yaitu (1) unit gramatikal, sebagai contoh penerjemahan nomina harus menjadi nomina, verba menjadi verba, semua frasa dan kalimat harus utuh, mempertahankan indikator formal; (2) konsistensi pada penggunaan kata; dan (3) makna pada teks sumber, tidak boleh membuat idiom, dan akan menghasilkan eksperimen yang literal. Sedangkan kesepadanan dinamis merupakan kebalikan dari kesepadaan formal. Kesepadanan dinamis berfokus pada pesan bahasa sumber untuk disampaikan kepada pembaca. Kesepadanan dinamis mengandung tida hal utama, yaitu (1) ekuivalensi dengan pesan pada bahasa sumber; (2) kewajaran yang mengacu pada bahasa sasaran; dan (3) kedekatan yang berorientasi pada ringkat kedekatan (Retsker, 2019). konsep kesepadanan formal dan dinamis yang diungkapkan Nida ini merupakan teori yang abadi dalam dunia 
penerjemahan. Dua pendekatan ini selalu menjadi acuan, karena mampu diaplikasikan dengan mudah dan sesuai dengan konsep kekinian.

Jika Retsker mengungkapkan dua tipe kesepadanan, Munday (2018) mengungkapkan lima tipe kesepadanan. Pertama, kesepadanan denotatif yang berkaiyan dengan kesepadanan bentuk ekstralinguistik teks disebut juga dengan invarian isi. Kedua, kesepadanan konotatif berkaitan dengan dengan pilihan leksikal, khususnya sinonim yang berdekatan atau identik dengan kesepadanan stilistika. Ketiga, kesepadanan teks-normatif yang berkaitan dengan jenis teks, dengan kata lain, jenis teks yang berbeda diperlukan dengan cara yang berbeda. Keempat, kesepadanan pragmatik atau kesepadanan komunikatif yang berorientasi kepada pembaca teks atau pesan. Kelima adalah kesepadanan formal yang berkaitan dengan bentuk dan estetika teks, termasuk permainan kata dan fitur stilistika individu pada bahasa sumber.

Terkait dengan kesepadanan ini, Baker (2011:20-48) mengemukakan kesepadanan pada pada tataran kata dan tataran diatas kata dan mengusulkan strategi bagaimana menerjemahkannya. Masalah umum kenapa terjadi ketidaksepadanan pada tataran kata, yaitu antara lain; (1) konsep budaya yang berbeda antara Bsu dan Bsa, (2) konsep kata tersebut tidak ada pada Bsa, (3) kata tersebut pada tataran gramatikal sulit diterjemahkan, (4) Bsa kekurangan istilah yang spesifik untuk menggambarkan kata tersebut.

\section{Analisis Isi}

a. FVG yang diterjemahkan dengan menggunakan prosedur Wort für Wort

TSu: Riccio konnte ihn zum Lachen bringen. (h. 55)

TSa: Riccio mampu membuatnya tertawa. (h. 49)

Prosedur penerjemahan Wort für Wort (kata untuk/demi kata) adalah prosedur penerjemahan yang mempertahankan kalimat asli. Penerjemah mempertahankan jumlah, jenis dan posisi kata. Penerjemah mempertahankan makna verba modal konnte dengan padanan yang sama dalam bahasa sasaran dan FV bringen tetap berfungsi sebagai verba, dan sama seperti konstruksi FVG pada bahasa sumber. Makna kata FV juga tetap yaitu kausatif.

b. FVG yang diterjemahkan dengan menggunakan prosedur Expansion

TSu: "Aber Scipio will ihn erst öffnen, wenn wir im Versteck sind.” (h. 99)

TSa: " Tapi Scipio baru membukanya setelah kita kembali ke tempat persembunyian." (h. 109)

Prosedur penerjemahan Expansion adalah prosedur penerjemahan ketika jumlah kata pada TSa lebih besar dibandingkan dengan TSu. FVG im Versteckt sind diterjemahkan 
menjadi kita kembali ke tempat persembunyiannya. Perubahan jumlah kata pada TSa disebabkan karena penerjemah mangubah FV dari fungsi dari duratif menjadi kausatif sehingga kata sein (berada) menjadi kembali ke tempat.

\section{c. FVG yang diterjemahkan dengan menggunakan prosedur Reduktion}

TSu: Es musste ein Kino sein, das nicht mehr im Betrieb war. (h. 117)

TSa: Berarti bioskop yang tidak beroperasi. (h. 127)

Prosedur penerjemahan Reduktion adalah prosedur penerjemahan ketika jumlah kata pada TSa lebih lebih sedikit dibandingkan dengan TSu. Prosedur penerjemahan Reduktion adalah kebalikan dari prosedur penerjemahan Expansion. FVG im Bertieb war (dalam situasi berfungsi) menjadi beroperasi. Penerjemah mengubah makna verba pada FV dari duratif menjadi inchoatif. Perubahan ini menyebabkan perubahan jumlah kata pada kedua klimat tersebut berubah.

\section{d. FVG yang diterjemahkan dengan menggunakan prosedur Transposition}

TSu: .., dass er die Schritte erst hörte, als sie vor seiner Tür Halt machten. (h. 8)

TSa: .. sehingga suara langkah di tangga itu baru diperhatikannya sewaktu berhenti di depan pintunya.(h. 10)

Pada prosedur penerjemahan Transposition, penerjemah mengubah satu jenis kata (Wortart) TSu menjadi jenis kata yang pada TSa. Pada pasangan kalimat diatas, penerjemah mengubah beberapa hal ke dalam T Sa, antara lain; (a) perubahan pada FV, (b) perubahan pada bentuk FVG dan (c) perubahan pada makna kata kerja / Aktionsart. FV machen yang pada TSu berfungsi kata keja bantu, pada TSa maknanya hilang dan melebur pada makna nomina pada FVG tersebut. Sehingga konstruksi awal melakukan pemberhentian di depan sesuatu menjadi berhenti di depan sesuatu. Berdasarkan data temuan, sebagian besar prosedur penerjemahan yang dilakukan oleh penejemah adalah prosedur penerjemahan Transposition.

e. FVG yang diterjemahkan dengan menggunakan prosedur Transformation

TSu: Meistens zogen Rizzio und Mosca los, wenn es um das Beobachten der Paläste ging, denen Scipio einen näctlichen Besuch abstatten wollte.(h.27)

TSa: Riccio dan Mosca-lah yang biasanya berangkat untuk mengamati istanaIstana yang hendak disatroni Scipio pada malam itu.(h. 30) 
Prosedur penerjemahan Transposition adalah prosedur penerjemahan yang mengubah satu struktur kalimat menjadi struktur yang lain. Pada TSu, FVG pada kalimat tersebut adalah aktif dan terjemahkan menjadi kalimat pasiv. Kalimat denen Scipio einen näctlichen Besuch abstatten wollte adalah aktif, diterjemahkan menjadi disatroni (Pasiv).

\section{f. Kesepadanan penerjemahan FVG}

Berdasarkan data yang disedkripsikan terlihat bahwa kesepadanan komunikatif digunakan paling banyak digunakan. Tercatat 124 kalimat atau sama dengan 90,5 \% diterjemahkan dengan menggunakan kesepadanan komunikatif, dan posri lainnya termasuk kesepadanan semantik.

\section{1) FVG dengan kesepadanan komunikatif}

TSu: .. er warf Prosper einen besorgten Blick zu.(h. 44)

TSa: .. dia melirik Prosper dengan khawatir.(h. 48)

Pada kesepadanan komunikatif, penerjemah berorientasi pada TSu, ia tidak terpaku pada TSa karena fokus proses penerjemahan adalah Adressat (Pembaca produkt penerjemahan). Pada konsep kesepadanan komunikatif, penerjemah akan brupaya sebisa mungkin sehingga TSa akan lebih natural dan kesan proses penerjemahan sudah tdk terlihat lagi. Pada kalimat diatas, penerjemah tidak hanya mengubah FVG menjadi kalimat biasa dan menghilangkan ciri FVG yaitu terdiri dari FV dan Nomina, tetapi juga adjektiva besorgt menjadi adverbia dengan khawatir. Dengan perubahan-perubahan yang dilakukan tersebut membuat TSa menjadi lebih natural. Di sebagian besar TSa, penerjemah berhasil melakukan itu dengan berhasil.

2) FVG dengan kesepadanan semantik

TSu: , offenbar versuchte sie ihn zum Lachen zu bringen.(h. 88)

TSa: , sepertinya ia berusaha membuat nya tertawa.(h. 96)

Berbeda dengan kesepadanan komunikatif, pada kesepadanan semantik, penerjemah berorientasi pada TSu. Penerjemah masih mempertahan bentuk bentuk dan pola TSu sehingga bentuk dan pola TSu masih bisa dirasakan pada TSa. Das Endprodukt (hasil) penerjemahan dengan kesepadanan semantik masih tidak natural. Hal itu masih dilihat pada pasangan klaimat diatas. Jika kita bandingkan kedua kalimat tersebut, pola susunan kata dan jenis kata pada kedua kalimat tersebut masih identik.

Dari data yang telah dikumpulkan dan dikelompokkan, dapat dideskripsikan bahwa dalam novel Herr der Diebe terdapat 137 data. FVG tersebut diterjemahkan ke dalam bahasa Indonesia dengan prosedur yang berbeda-beda. Enam belas (16) kalimat atau 11, 67 
\% diterjemahkan dengan prosedur Wort für Wort Übersetzung, tidak ada kalimat yang terjemahkan dengan menggunakan prosedur Permutasi, 4 kalimat atau 2, $94 \%$ diterjemahkan dengan menggunakan prosedur penerjemahan Exspansi, 15 kalimat atau 11, $02 \%$ kalimat diterjemahkan menggunakan prosedur Reduksi, tidak ada kalimat yang diterjemahkan menggunakan prosedur Intrakategorialer Wechsel, 111 kalimat atau 81, 61\% diterjemahkan menggunakan prosedur terjemahan Transposisi dan 4 kalimat atau 2, $94 \%$ diterjemahkan menggunakan prosedur Transformation. Pada tataran analisis kesepadanan (equivalensi) ditemukan bahwa sebagian besar kalimat diterjemahkan dengan menggunakan prosedur penerjemahan dinamis, yaitu sebanyak 124 kalimat atau 90, $5 \%$. Sementara 4 kalimat atau 2,9\% diterjemahkan dengan menggunakan prosedur penerjemahan formal. Dari 137 kalimat yang dianalisis, 9 kalimat atau 5,6 \% diterjemahkan dengan cara kurang tepat. Pada ke 9 kalimat tersebut ditemukan penyimpangan makna yang diakibatkan karena berbagai hal yang akan diterangkan pada sub bab yang akan datang.

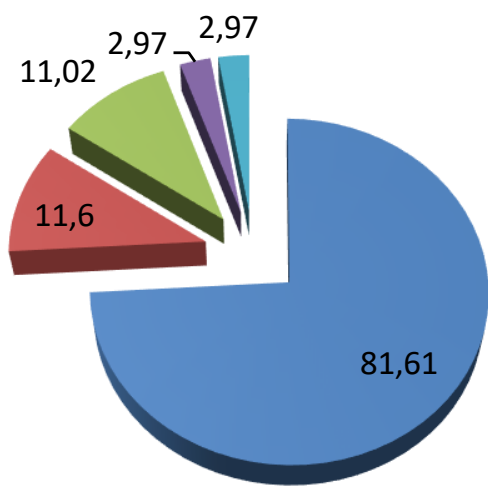

- Transposition

- Wort fuer Wort

Reduktion

Expansion

- Transformation

Diagram 1. Prosedur Penerjemahan FVG dalam Novel Herr der Diebe ke dalam bahasa Indonesia

\section{KESIMPULAN}

Dari rumusan masalah dan analisis yang dilakukan dapat disimpulkan bahwa prosedur penerjemahan yang yang paling banyak dilakukan untuk menerjemahkan FVG ke dalam bahasa Indonesia adalah prosedur penerjemahan Transposition. Terdapat 111 kalimat atau $81,61 \%$ diterjemahkan dengan melakukan perubahan FVG ke dalam bentuk yang berbeda. Konstruksi FVG yang pada TSu terdiri dari FV dan Nomina dalam akkusatif atau FV + Kata Depan dan Nomina, pada TSa diganti dengan kelas kata yang lain, sehingga konstruksi FVG sudah tidak ada. Hasil penerjemahan kalimat-kalimat menjadi lebih luwes 
dan tidak kaku. Penerjemahan FVG tersebut dapat dikatakan berhasil karena TSa menjadi natural.

Penemuan kedua yang didapat dari penelitian ini berkaitan dengan kesepadanan penerjemahan FVG ke dalam bahasa Indonesia. Didapati bahwa 90, 5 \% atau 124 kalimat yang menggunakan FVG diterjemahkan dengan menggunakan kesepadanan komunikatif. Penerjemahan FVG berorientasi pada teks sasaran (TSa) sehingga bentuk FVG pada TSa sudah tidak ada. Das Endprodukt (hasil) penerjemahan menjadi lebih natural dan tidak kaku sehingga Adressat (pembaca hasil penerjemahan) tidak mendapatkan kesan bahwa mereka sedang membaca novel terjemahan. Penerjemahan FVG pada korpus data ini bisa dikatakan berhasil.

Temuan ketiga penelitian ini terkait dengan penyimpangan penerjemahan FVG. Dari data yang ditemukan bahwa dari 11 penyimpangan, sebagian besar terjadi karena penerjemah menggunakan bahasa individu. Penyimpangan lain disebabkan karena adanya kata/frase yang tidak diterjemahkan. Penghilangan kata menyebabkan informasi pada TSa menjadi tidak utuh. Penyimpangan-penyimpangan yang ditemukan terjadi karena usaha keberanian penerjemah untuk tidak berorientasi pada TSu. Penyimpangan-penyimpangan tersebut karenanya masih wajar.

\section{DAFTAR PUSTAKA}

Alwi, H., Dardjowidjojo, S., Lapoliwa, H., \& Moeliono, A. M. (2000). Tata Bahasa Baku Bahasa Indoneisa, edisi ketiga. Jakarta: Balai Pustaka.

Baker, M. (2011). In Other Words: A coursebook on translation, second edition. In Other Words: A coursebook on translation.

Dennis, M. O. (2019). Learner Perceptions of Using Machine Translation Tools in the EFL Classroom. The SNU Journal of Education Research, 28(2), 63-83.

Helbig, G., \& Buscha, J. (2001). Deutsche Grammatik-ein Handbuch für den Ausländerunterricht. Berlin-München-Wein-Zürich-New York: Langenscheidt.

Jakobson, R. (2013). On Linguistic Aspects of Translation. In On Translation. https://doi.org/10.4159/harvard.9780674731615.c18

Joyce, P. (2018). L2 vocabulary learning and testing: The use of L1 translation versus L2 definition. The Language Learning Journal, 46(3), 217-227.

Koller, W. (2011). The Concept of Equivalence and the Object of Translation Studies. TargetTarget International Journal of Translation Studies. https://doi.org/10.1075/target.7.2.02kol

Mihyung, O., Soonyoung, K., \& Montgomery, C. (2016). Exploring Distinctiveness In The Translation Of Korean Allusions. Acta Koreana, 19(1), 331.

Moleong, L. J. (2017). Metodologi Penelitian Kualitatif (Edisi Revisi). PT. Remaja Rosda 
Karya.

Munday, J. (2018). Introducing Translation Studies. Introducing Translation Studies. https://doi.org/10.4324/9781315691862

Namikawa, T., Munekage, M., Yatabe, T., Kitagawa, H., \& Hanazaki, K. (2018). Current status and issues of the artificial pancreas: abridged English translation of a special issue in Japanese. Journal of Artificial Organs, 21(2), 132-137

Oppenheim, G., Wu, Y. J., \& Thierry, G. (2018). Found in translation: Late bilinguals do automatically activate their native language when they are not using it. Cognitive science, 42(5), 1700-1713.

Retsker, J. (2019). The theory and practice of translation. In Translation as Social Action. https://doi.org/10.4324/9780429429637-4

Saleh, N., Saud, S., \& Asnur, M. N. A. (2018). Pemanfaatan QR-Code sebagai media pembelajaran Bahasa Asing pada Perguruan Tinggi di Indonesia. In Seminar Nasional Dies Natalis UNM 57 (pp. 253-260).

Santos Jr, H. P., Black, A. M., \& Sandelowski, M. (2015). Timing of translation in crosslanguage qualitative research. Qualitative health research, 25(1), 134-144.

Shadiev, R., Wu, T. T., Sun, A., \& Huang, Y. M. (2018). Applications of speech-to-text recognition and computer-aided translation for facilitating cross-cultural learning through a learning activity: issues and their solutions. Educational Technology Research and Development, 66(1), 191-214

Snell-Hornby, M. (1998). Handbuch Translation. Tübingen: Staufeffenberg.

Soloway, E., Norris, C., \& Hossain, A. (2011). Using Smartphones as Essential Tools for Learning. Educational Technology, (June), 18-25.

Wael, A., Asnur, M. N. A., \& Ibrahim, I. (2018). Exploring Students' Learning Strategies in Speaking Performance. International Journal of Language Education, 2(1), 65. https://doi.org/10.26858/ijole.v2i1.5238

Wills, W. (1977). Ubersetzungswissenschaft, Probleme und Methode. Stuttgart: Klett.

Wilss, W. (2011). Werner Koller. Einführung in die Übersetzungswissenschaft . TargetTarget International Journal of Translation Studies

Ying, B. T., Hoon, A. L., Halim, H. A., \& Majtanova, M. (2018). Students' beliefs on translation strategy in learning German language. GEMA Online ${ }^{\circledR}$ Journal of Language Studies, 18(1). 